\title{
Article \\ Foliar Calcium Fertilizers Impact on Several Fruit Quality Characteristics and Leaf and Fruit Nutritional Status of the 'Hayward' Kiwifruit Cultivar
}

\author{
Thomas Sotiropoulos ${ }^{1, *}$, Antonios Voulgarakis ${ }^{2}$, Dionisios Karaiskos ${ }^{2}$, Theocharis Chatzistathis ${ }^{3}$, \\ Ioannis Manthos ${ }^{4}$, Olga Dichala ${ }^{5}\left(\mathbb{D}\right.$ and Areti Mpountla ${ }^{3}$ \\ 1 Hellenic Agricultural Organization 'Demeter', Institute of Plant Breeding and Genetic Resources, Department \\ of Deciduous Fruit Tree Growing, 59035 Naoussa, Greece \\ 2 NATURE SA, Nea Efessos, 60100 Pieria, Greece; voulgarakis.antonis@naturefert.com (A.V.); \\ dkaraisk@yahoo.com (D.K.) \\ 3 Hellenic Agricultural Organization 'Demeter', Institute of Soil and Water Resources, Thermi, \\ 57001 Thessaloniki, Greece; chchatzista@gmail.com (T.C.); a.bountla@swri.gr (A.M.) \\ 4 Hellenic Agricultural Organization 'Demeter', Institute of Plant Breeding and Genetic Resources, Department \\ of Nut Trees, 35100 Neo Krikello-Lamia, Greece; manthosjo@yahoo.gr \\ 5 Hellenic Agricultural Organization 'Demeter', Institute of Plant Breeding and Genetic Resources, Thermi, \\ 57001 Thessaloniki, Greece; olga.dichala@gmail.com \\ * Correspondence: thosotir@otenet.gr
}

check for updates

Citation: Sotiropoulos, T.; Voulgarakis, A.; Karaiskos, D.; Chatzistathis, T.; Manthos, I.; Dichala, O.; Mpountla, A. Foliar Calcium Fertilizers Impact on Several Fruit Quality Characteristics and Leaf and Fruit Nutritional Status of the 'Hayward' Kiwifruit Cultivar. Agronomy 2021, 11, 235. https:// doi.org/10.3390/agronomy11020235

Academic Editor: Sara Serra Received: 19 December 2020 Accepted: 20 January 2021 Published: 27 January 2021

Publisher's Note: MDPI stays neutral with regard to jurisdictional claims in published maps and institutional affiliations.

Copyright: (c) 2021 by the authors. Licensee MDPI, Basel, Switzerland. This article is an open access article distributed under the terms and conditions of the Creative Commons Attribution (CC BY) license (https:/ / creativecommons.org/licenses/by/ $4.0 /)$.

\begin{abstract}
Calcium preharvest application influences fruit quality. The impact of preharvest foliar sprays using several commercial fertilizers with Ca content on the fruit quality and nutritional status of the kiwi cv. 'Hayward' was investigated for a 2-year period. Fruit flesh firmness increased under all Ca sprays compared to the control. Total soluble solids and acidity were not altered significantly by any of the studied Ca products. Treatment differences with regard to fruit firmness, soluble solids concentration and acids at harvest were maintained during cold storage for 2 and 4 months. Foliar sprays did not affect the N, P, K, Mg, B, Fe, Mn and $\mathrm{Zn}$ concentrations of leaves and fruits. However, all treatments increased the concentration of $\mathrm{Ca}$ in leaves and fruits compared to the control.
\end{abstract}

Keywords: foliar fertilization; fruit firmness; storability

\section{Introduction}

Kiwifruit is a climacteric fruit with a long postharvest life in cool storage. Calcium (Ca) is a fundamental nutrient related to qualitative characteristics in kiwifruit. Calcium has been referred to as both (i) an essential element and (ii) a nutrient significantly contributing to the maintenance of high postharvest fruit quality.

It also has significant roles in plant physiology, such as a structural function in the cell wall and membranes; a counter ion for inorganic and organic anions in the vacuole; and a cytoplasmic secondary messenger associated with environmental or developmental stimuli and their physiological responses [1].

The Ca effect on the integrity of the cell membrane and its synergetic role with boron (B) in the plant cell wall's build is well documented [2]. The stability of the cell wall relates to the cooperative binding of polygalacturonate chains with $\mathrm{Ca}$ ions, forming the cell wall of the fruit interior accessible to enzymes that generate softening or to cell wall denigrative enzymes caused by fungi. Enhancing the fruit Ca content may influence storability by its function in binding the pectin in cell walls and posterior blocking of the access of degrading enzymes, e.g., polygalacturonase [3]. Kiwifruit undergoes physiological disorders during storage [4]. Losses in kiwifruit are mostly due to its relatively high metabolic activity during storage [5]. Fruit softening is frequently ascribed to modifications in cell wall structure 
and, specifically, to the effect of pectin de-esterification and Ca crosslink arrangement on cell wall physical characteristics involving strength and elasticity, cell wall loosening and swelling.

The water delivery and cell wall interactions in the apoplasm affect, to a great extent, the $\mathrm{Ca}$ accumulation and allocation in fruit. Localized $\mathrm{Ca}$ deficiencies detected in particular species may originate from alterations in xylem morphology, fruit water relations and pectin composition and can potentially cause porous membranes, irregular cell wall weakening, impaired hormonal signaling and abnormal fruit growth [6].

Calcium is mainly transported by the xylem. High growth together with low transpiration rates in fruits lowers the Ca content, which may fall below the critical level of deficiency, which is necessary for a good cell wall structure and membrane [7]. Consequently, low Ca uptake and transportation via the xylem may cause fruit disorders. In kiwifruit, xylem operating, fruit transpiration, fruit hair viability and fruit hydraulic conductance showed significant alterations during the first 8-10 weeks after full bloom [8]. Each of these factors can be responsible for the primal discontinuance of Ca import into the fruit. Xylem transport happens only in the acropetal direction and is of some significance for the Ca supply of young fruits which yet transpire in the early phase of their development. In later stages, fruits mainly feed from the phloem [9]. The phloem transport system happens through the cytoplasm, which has low concentrations of Ca [10]. Due to its phloem immobility, foliage-applied $\mathrm{Ca}$ is not reallocated from treated leaves to the fruit [11].

Early fruit development is the most pivotal period for $\mathrm{Ca}$ accumulation in most fleshy fruits, including kiwifruit. Predominantly, this happens due to the fact that $\mathrm{Ca}$ is xylemmobile but phloem-immobile [12]. Thus, the Ca import rate is determined by the xylem sap in the flow rate to the fruit. In the early season, for most of the fleshy fruits, the phloem and xylem saps' influxes are similar [13], while in the late season, the inflow of the total sap is principally dominated by the phloem, with the xylem sap in flow being insignificant due to the transpiration's dynamic decline [14,15]. Hence, in the initial stages of kiwifruit development (approximately from day 10 to day 50 after fruit set), a deduction in atmospheric vapor pressure deficit causes a reduction in several processes such as fruit transpiration, fruit xylem sap inflow and, seemingly, Ca import [16]. Whilst for transpiring organs, their transpiration presumably remains the dominant driver for Ca accretion, within-plant transport and partitioning of $\mathrm{Ca}$ and other minerals are also considered to be affected by factors not related to transpiration. For instance, the Ca requirement by an organ and the physicochemical features of the conducting tissues (e.g., ion adsorption and desorption occurring at exchange sites across the walls of the xylem pathway) are probable to impact the metabolic movement of Ca [17]. Furthermore, the action of specialized transfer cells and the higher expression of Ca transporters and $\mathrm{Ca}$ binding proteins may advance accumulation of $\mathrm{Ca}$ into the fruit unassisted by its transpiration $[18,19]$. Results indicate that $\mathrm{Ca}$ accumulation is coupled to accretive transpiration under high vapor pressure deficit because under that condition, cumulative transpiration equates liken xylem stream. At low vapor pressure deficit, Ca gain by fruit is uncoupled from transpiration because $\sim 60 \%$ of the xylemic water is necessary to endure fruit growth [20].

The critical factors affecting Ca delivery and distribution in aerial tissues involve: the rate of xylem water mass flow, the competition between ions for binding sites in xylem vessel walls and pit membranes, formation of lowly soluble or insoluble complexes (e.g., calcium oxalate) and cellular water/ionic transport mechanisms [14,21,22].

Calcium availability in acid soils is low [9]. Although $\mathrm{Ca}$ is the most common exchangeable cation in calcareous soils, fruit Ca content is fairly low [23]. Therefore, for specific fruit trees, applying a preharvest foliar Ca spray is a usual practice in order to enhance fruit Ca content. Nevertheless, the impact of foliar Ca spray on the Ca content and the prevalence of disorders in fruit are sometimes discrepant. For efficient foliar $\mathrm{Ca}$ application, the physical characteristics of Ca salts can unveil eloquent information. There are three implicit accountings for inconsistencies of Ca treatments: (a) atmospheric effects of $\mathrm{Ca}$ 
absorption, (b) abnormal Ca distribution of Ca in fruit within the canopy and (c) tree management and cultivation [6].

The aim of this research is to analyze the impact of foliar sprays using several commercial products with Ca content on the fruit quality and nutritional status of the kiwi cv. 'Hayward'.

\section{Materials and Methods}

The research was conducted for two consecutive years (2018 and 2019) in a commercial kiwifruit (Actinidia deliciosa (A. chev.) C.F. Liang et A.R. Ferguson var. deliciosa) orchard located in Naoussa (northern Greece, long. 22012'0" E; lat. $40029^{\prime} 04^{\prime \prime} \mathrm{N}$; elevation $350 \mathrm{~m}$ ). The vines of the cultivar 'Hayward' (Apostolou Nurseries, Episkopi, Naoussa, Greece) were 13 years old, planted at a spacing of $4 \times 3.5 \mathrm{~m}$ and trained in a T-bar trellis system [24]. The trees received standard horticultural practices regarding pruning, irrigation and fertilization.

Soil samples from the experimental orchard were collected from a depth of 0-60 cm and analyzed [25]. The soil was characterized as sandy loam, slightly alkaline ( $\mathrm{pH} 7.9)$, with low electrical conductivity $\left(1.30 \mathrm{mS} \mathrm{cm}^{-1}\right)$, organic matter content $3.5 \%$ and calcium carbonate content $13.3 \%$. Concerning nutrients in the soil, their concentrations are shown in Table 1.

Table 1. Soil nutrient concentrations $\left(\mathrm{mg} \mathrm{kg}^{-1}\right.$ ) of the experimental orchard.

\begin{tabular}{cccccccc}
\hline $\mathbf{P}$ & $\mathbf{K}$ & $\mathbf{C a}$ & $\mathbf{M g}$ & $\mathbf{B}$ & $\mathbf{M n}$ & $\mathbf{Z n}$ & $\mathbf{F e}$ \\
\hline 39 & 383 & 1560 & 548 & 0.49 & 18.41 & 2.49 & 13.82 \\
\hline
\end{tabular}

Fertilization of the orchard was performed using soil and leaf analyses data. Five foliar sprays (with 30-day interval) were applied by a hand sprayer (Comfort Backup Sprayer 12 L, Gardena, Ulm, Germany) starting on June 2 with the following products: (1) Profical $(\% w / v \mathrm{CaO} 17, \mathrm{MgO} 5$, organic matter, 10); (2) Chelan $\mathrm{Ca}(\%$ w/v N 12, $\mathrm{CaO} 21, \mathrm{MgO} 2.8$, $\mathrm{Cu}$ 0.014, Fe 0.014, Mn 0.014, Zn 0.014, Mo 0.0014, organic matter 2.8), (3) F-away Ca (\% w/w $\left.\mathrm{P}_{2} \mathrm{O}_{5} 20, \mathrm{CaO} 5\right)$; (4) F-away Ca plus Profical; (5) F-away Ca plus Chelan Ca (Nature S.A. Nea Efessos, Pieria, Greece. Fertlizer doses are shown in Table 2.

Table 2. Fertilizer doses $\left(\mathrm{L} \mathrm{t}^{-1}\right)$.

\begin{tabular}{cc}
\hline Fertilizer & Dose \\
\hline Profical & 3 \\
Chelan Ca & 2.42 \\
F-away Ca & 4 \\
F-away Ca + Profical & $3+1.8$ \\
F-away Ca + Chelan Ca & $3+1.5$ \\
\hline
\end{tabular}

Ca concentration of the spray solution was maintained the same for all treatments. Control vines were sprayed with water. A surfactant was also added (Shinulin: ethoxylated isodecyl alcohol; Farma Chem S.A., Thessaloniki, Greece; $0.3 \mathrm{~L}$ per tone).

Leaf samples were collected manually at midsummer (25 July). Each leaf sample consisted of the third leaf past the final fruit on a fruiting lateral. Fruit flesh analysis was carried out on samples taken at harvest. All samples were initially washed once with tap water and twice with distilled water. Leaf samples were dried in a forced draft oven at $68{ }^{\circ} \mathrm{C}$ for $72 \mathrm{~h}$ and ground in a mill to pass a 30-mesh screen. Nitrogen was determined by Kjeldahl's procedure, B by the azomethine- $\mathrm{H}$ method [26], $\mathrm{P}$ by the ammonium phosphovanadomolybdate method [27] and $\mathrm{K}, \mathrm{Ca}, \mathrm{Mg}, \mathrm{Fe}, \mathrm{Mn}$ and $\mathrm{Zn}$ by atomic absorption spectrophotometry. Fruit samples (20 per replication) were collected manually in mid-October (harvest period). 
One hundred fruits were collected from the five trees of each replication, and therefore we collected 20 fruit per tree. Fruits were sampled at commercial maturity. Fruits from all treatments were harvested at the same time, based on total soluble solids concentration. Fruits were transported immediately to the laboratory for analyses.

Ten fruits per tree were weighted and evaluated individually for soluble solids (\%) after extracting the juice of all fruits. Soluble solids were measured with an Atago PR1 electronic refractometer (Atago Inc., Bellevue, WA, USA), acidity was measured after titration was measured with $0.1 \mathrm{~N} \mathrm{NaOH}$ [28], flesh firmness was measured with an Effegi penetrometer with an 8-mm tip (Effegi Model FT 327, Alfonsine, Italy) and dry matter was measured according to [29]. Lastly, the remaining 10 fruits per tree were placed into a cooling chamber $\left(+0.5^{\circ} \mathrm{C}\right)$ for four months. For these fruits, the same quality attributes were determined.

The adopted experimental design was a randomized block with five replications of 6 treatments (five vines per replication were used). Differences between means were evaluated by using Tuckey's test $(p \leq 0.05)$. Statistical analysis was performed using SPSS statistical package (SPSS Statistics for Windows, Version 17.0. SPSS Inc.; 2008, Chicago, IL, USA).

\section{Results}

All Ca sprays increased fruit flesh firmness compared to the control (Table 3). In another experiment, kiwifruit cv. 'Hayward', during fruit development, was sprayed up to three times with $\mathrm{CaCl}_{2}$. Kiwifruits sprayed preharvest with $\mathrm{CaCl}_{2}$ solutions exhibited lower softening rates compared to the controls at both 20 and $0{ }^{\circ} \mathrm{C}$ storage temperatures and quality was maintained [30]. Different formulations of $\mathrm{Ca}$ such as $\mathrm{CaCl}_{2}$ and a commercial product, Calbit, at the application rate of $1 \% \mathrm{Ca} w / v$, were used by Hashmatt et al. [31]. The treatments were applied five times at weekly intervals at the late fruit developmental stage. Firmness was significantly increased by $22 \%$ and the total soluble solids were significantly reduced by $4 \%$ due to $\mathrm{CaCl}_{2}$ compared to the control [32]. The one-time (early, mid or late fruit growing season) spray of $\mathrm{CaCl}_{2}$ had no significant effect on firmness as compared with the control, whereas the highest fruit firmness was obtained in the four and five foliar sprays treatments [31].

Table 3. Kiwifruit weight, fruit firmness, total soluble solids, total titratable acidity and dry matter during harvest (means of 2 years).

\begin{tabular}{cccccc}
\hline Treatments & $\begin{array}{c}\text { Fruit } \\
\text { Firmness } \\
\left(\mathbf{k g ~ c m}^{-2} \mathbf{)}\right.\end{array}$ & $\begin{array}{c}\text { Total Soluble } \\
\text { Solids (\%) }\end{array}$ & $\begin{array}{c}\text { Total } \\
\text { Titratable Acidity } \\
\text { (\% Citric Acid) }\end{array}$ & $\begin{array}{c}\text { Mean Fruit } \\
\text { wt (g) }\end{array}$ & Dry Matter (\%) \\
\hline Control & $6.49 \mathrm{c}^{\mathrm{z}}$ & $6.86 \mathrm{a}$ & $1.24 \mathrm{a}$ & $128 \mathrm{a}$ & $17.15 \mathrm{~b}$ \\
Profical & $7.44 \mathrm{ab}$ & $6.86 \mathrm{a}$ & $1.25 \mathrm{a}$ & $124 \mathrm{a}$ & $17.35 \mathrm{~b}$ \\
Chelan Ca & $7.44 \mathrm{ab}$ & $6.79 \mathrm{a}$ & $1.33 \mathrm{a}$ & $126 \mathrm{a}$ & $16.96 \mathrm{~b}$ \\
F-away Ca & $7.52 \mathrm{a}$ & $6.90 \mathrm{a}$ & $1.27 \mathrm{a}$ & $126 \mathrm{a}$ & $18.88 \mathrm{~b}$ \\
F-away Ca + Profical & $7.58 \mathrm{a}$ & $6.92 \mathrm{a}$ & $1.28 \mathrm{a}$ & $125 \mathrm{a}$ & $19.02 \mathrm{a}$ \\
F-away Ca + Chelan Ca & $7.57 \mathrm{a}$ & $6.82 \mathrm{a}$ & $1.24 \mathrm{a}$ & $\mathrm{a}$ & \\
\hline
\end{tabular}

${ }^{\mathrm{z}}$ Means within columns and years followed by common letters are not significantly different (Tukey's test, $p \leq 0.05$ ).

The mean fruit weight was not affected by the foliar application of all Ca products compared to control. Koutinas et al (2010) observed that preharvest foliar sprays with various commercial products containing $\mathrm{Ca}$, over a 2- year period, affected significantly various fruit quality attributes and nutritional status of 'Tsechelidis' kiwifruit cultivar [33]. Foliar application of all Ca products tested plus boron did not affect mean fruit weight compared with the control.

None of the studied Ca products significantly altered total soluble solids and acidity. The total soluble solids were reduced by $4 \%$ due to $\mathrm{CaCl}_{2}$ compared to the control [31]. Dry matter content of fruits was improved after application of F-away $\mathrm{Ca}+$ Profical and 
F-away $\mathrm{Ca}+\mathrm{Chelan} \mathrm{Ca}$ compared to the rest of the treatments. Fruit dry matter content was non-significantly increased by 3 and $7 \%$ due to $\mathrm{CaCl}_{2}$ and Calbit respectively, compared to the control [31].

We further examined fruit quality attributes of kiwis stored for 2 and 4 months in cooling chambers. The fruit soluble solids concentration increased, whereas total titratable acidity decreased with respect to the harvest stage (Tables 4 and 5). The decay percentage of kiwifruit significantly suppressed by thrice $\mathrm{CaCl}_{2}$ sprays [32]. Furthermore, fruit firmness slightly decreased during 90 days of cold storage from 7.89 to $4.99 \mathrm{~kg} \mathrm{~cm}^{-2}$ according to the previous authors.

Table 4. Fruit firmness, total soluble solids and total titratable acidity after two months of cold storage (means of 2 years).

\begin{tabular}{cccc}
\hline Treatments & $\begin{array}{c}\text { Fruit } \\
\text { Firmness } \\
\left(\mathbf{k g ~ c m}^{\mathbf{2}} \mathbf{)}\right.\end{array}$ & $\begin{array}{c}\text { Total Soluble } \\
\text { Solids (\%) }\end{array}$ & $\begin{array}{c}\text { Total } \\
\text { Titratable Acidity } \\
\mathbf{( \% ~ C i t r i c ~ A c i d ) ~}\end{array}$ \\
\hline Control & $4.07 \mathrm{~b}^{\mathrm{z}}$ & $12.06 \mathrm{a}$ & $1.00 \mathrm{a}$ \\
Profical & $5.05 \mathrm{a}$ & $11.93 \mathrm{a}$ & $1.07 \mathrm{a}$ \\
Chelan Ca & $5.23 \mathrm{a}$ & $12.22 \mathrm{a}$ & $1.05 \mathrm{a}$ \\
F-away Ca & $5.22 \mathrm{a}$ & $12.29 \mathrm{a}$ & $1.03 \mathrm{a}$ \\
F-away Ca + Profical & $5.28 \mathrm{a}$ & $11.75 \mathrm{a}$ & $1.04 \mathrm{a}$ \\
F-away Ca + Chelan Ca & $5.32 \mathrm{a}$ & $12.05 \mathrm{a}$ & $1.04 \mathrm{a}$ \\
\hline
\end{tabular}

${ }^{\mathrm{z}}$ Means within columns and years followed by common letters are not significantly different (Tukey's test, $p \leq 0.05$ ).

Table 5. Fruit firmness, total soluble solids and total titratable acidity after four months of cold storage (means of 2 years).

\begin{tabular}{cccc}
\hline Treatments & $\begin{array}{c}\text { Fruit } \\
\text { Firmness } \\
\left(\mathbf{k g ~ c m}^{-2}\right)\end{array}$ & $\begin{array}{c}\text { Total Soluble } \\
\text { Solids (\%) }\end{array}$ & $\begin{array}{c}\text { Total } \\
\text { Titratable Acidity } \\
\text { (\% Citric Acid) }\end{array}$ \\
\hline Control & $2.16 \mathrm{~b}^{\mathrm{z}}$ & $14.10 \mathrm{a}$ & $0.82 \mathrm{a}$ \\
Profical & $3.52 \mathrm{a}$ & $14.06 \mathrm{a}$ & $0.80 \mathrm{a}$ \\
Chelan Ca & $3.73 \mathrm{a}$ & $14.18 \mathrm{a}$ & $0.81 \mathrm{a}$ \\
F-away Ca & $3.74 \mathrm{a}$ & $14.31 \mathrm{a}$ & $0.77 \mathrm{a}$ \\
F-away Ca + Profical & $3.92 \mathrm{a}$ & $14.10 \mathrm{a}$ & $0.84 \mathrm{a}$ \\
F-away Ca + Chelan Ca & $3.91 \mathrm{a}$ & $14.42 \mathrm{a}$ & $0.83 \mathrm{a}$ \\
\hline
\end{tabular}

${ }^{\mathrm{z}}$ Means within columns and years followed by common letters are not significantly different (Tukey's test, $p \leq 0.05$ ).

Regarding the results of various treatments on fruit firmness, soluble solids concentration and acids at harvest were maintained during cold storage for 2 and 4 months. Fruit softening and water loss are the most important limiting factors during cold storage [33]. During storage, kiwifruit softens noticeably from 6 to $8 \mathrm{~kg} \mathrm{~cm}^{-2}$ at harvest to less than 1 when eaten ripe. The duration of the softening process determines the commercial life of fruit. Various preharvest factors influence the kiwifruit firmness as well as fruit-handling procedures [34]. Increasing fruit Ca concentration through preharvest foliar and fruit sprays with Ca solutions is one of the methods used to preserve firmness and quality characteristics during ripening and storage of fresh fruits $[35,36]$.

Foliar sprays did not affect the N, P, K, Mg, B, Fe, Mn and $\mathrm{Zn}$ concentrations of leaves and fruits (Tables 6 and 7). However, all treatments increased the concentration of $\mathrm{Ca}$ in leaves and fruits compared to the control. In vines sprayed 17 times with $\mathrm{CaCl}_{2}$ at $0.8 \%$ of the commercial product (1700 ppm Ca), fruit Ca content was higher and storage life was $50-80 \%$ greater than fruit from vines sprayed nine times and in fruit from control vines [37]. $\mathrm{CaCl}_{2}$ sprays increased fruit pericarp, core and skin $\mathrm{Ca}$ as reported by Gerasopoulos et al. (1996), who found that fruit pericarp, core and skin Ca was increased by $\mathrm{CaCl}_{2}$ sprays [30]. Fruit Ca content and other fruit quality characteristics were improved by foliar $\mathrm{Ca}$ application [30]. Foliar $\mathrm{Ca}$ application was beneficial to increase fruit $\mathrm{Ca}$ content and other fruit quality characteristics [31]. 
Table 6. Effect of foliar sprays on nitrogen $(\mathrm{N})$, phosphorus $(\mathrm{P})$, potassium $(\mathrm{K})$, calcium $(\mathrm{Ca})$, magnesium $(\mathrm{Mg})$, boron (B), manganese $(\mathrm{Mn})$, zinc $(\mathrm{Zn})$ and iron $(\mathrm{Fe})$ concentrations of the kiwifruit fruits (means of 2 years).

\begin{tabular}{|c|c|c|c|c|c|c|c|c|c|}
\hline Treatments & $\begin{array}{c}\mathrm{N} \\
\left(\mathrm{mg} \mathrm{g}^{-1}\right. \\
\text { dry } w \mathrm{t})\end{array}$ & $\begin{array}{c}P \\
\left(\mathrm{mg} \mathrm{g}^{-1}\right. \\
\text { dry } w t)\end{array}$ & $\begin{array}{c}\mathrm{K} \\
\left(\mathrm{mg} \mathrm{g}^{-1}\right. \\
\operatorname{dry} w \mathrm{t})\end{array}$ & $\begin{array}{c}\mathrm{Ca} \\
\left(\mathrm{mg} \mathrm{g}^{-1}\right. \\
\text { dry } w \mathrm{t})\end{array}$ & $\begin{array}{c}\text { Mg } \\
\left(\mathrm{mg} \mathrm{g}^{-1}\right. \\
\text { dry wt) }\end{array}$ & $\begin{array}{c}\text { B } \\
\left(\mu g g^{-1}\right. \\
\text { dry } w t)\end{array}$ & $\begin{array}{c}\text { Mn } \\
\left(\mu g g^{-1}\right. \\
\text { dry } w t)\end{array}$ & $\begin{array}{c}\mathrm{Zn} \\
\left(\mu \mathrm{g} \mathrm{g}^{-1}\right. \\
\text { dry wt) }\end{array}$ & $\begin{array}{c}\text { Fe } \\
\left(\mu g g^{-1}\right. \\
\text { dry } w t)\end{array}$ \\
\hline Control & $1.08 \mathrm{a}^{\mathrm{z}}$ & $0.59 \mathrm{a}$ & $1.58 \mathrm{a}$ & $0.20 \mathrm{~b}$ & $0.12 \mathrm{a}$ & $16 \mathrm{a}$ & $3 a$ & $5 \mathrm{a}$ & $13 \mathrm{a}$ \\
\hline Profical & $1.13 \mathrm{a}$ & $0.57 \mathrm{a}$ & $1.64 \mathrm{a}$ & $0.26 \mathrm{a}$ & $0.12 \mathrm{a}$ & $16 a$ & $4 \mathrm{a}$ & $7 \mathrm{a}$ & $13 \mathrm{a}$ \\
\hline Chelan Ca & $1.06 \mathrm{a}$ & $0.57 \mathrm{a}$ & $1.61 \mathrm{a}$ & $0.27 \mathrm{a}$ & $0.12 \mathrm{a}$ & $18 \mathrm{a}$ & $4 \mathrm{a}$ & $6 \mathrm{a}$ & $12 \mathrm{a}$ \\
\hline F-away Ca & $1.08 \mathrm{a}$ & $0.58 \mathrm{a}$ & $1.75 \mathrm{a}$ & $0.27 \mathrm{a}$ & $0.13 \mathrm{a}$ & $17 \mathrm{a}$ & $4 \mathrm{a}$ & $7 \mathrm{a}$ & $13 \mathrm{a}$ \\
\hline F-away Ca + Profical & $1.12 \mathrm{a}$ & $0.60 \mathrm{a}$ & $1.69 \mathrm{a}$ & $0.28 \mathrm{a}$ & $0.13 \mathrm{a}$ & $18 \mathrm{a}$ & $4 \mathrm{a}$ & $6 a$ & $13 \mathrm{a}$ \\
\hline F-away Ca + Chelan Ca & $1.04 \mathrm{a}$ & $0.58 \mathrm{a}$ & $1.68 \mathrm{a}$ & $0.28 \mathrm{a}$ & $0.12 \mathrm{a}$ & $16 \mathrm{a}$ & $4 \mathrm{a}$ & $6 a$ & $12 \mathrm{a}$ \\
\hline
\end{tabular}

${ }^{\mathrm{z}}$ Means within columns and years followed by common letters are not significantly different (Tukey's test, $\left.p \leq 0.05\right)$.

Table 7. Effect of foliar sprays on nitrogen $(\mathrm{N})$, phosphorus $(\mathrm{P})$, potassium $(\mathrm{K})$, calcium $(\mathrm{Ca})$, magnesium $(\mathrm{Mg})$, boron (B), manganese $(\mathrm{Mn})$, zinc $(\mathrm{Zn})$ and iron $(\mathrm{Fe})$ concentrations of the kiwifruit leaves (means of 2 years).

\begin{tabular}{|c|c|c|c|c|c|c|c|c|c|}
\hline Treatments & $\begin{array}{c}\mathrm{N} \\
\left(\mathrm{mg} \mathrm{g}^{-1}\right. \\
\text { dry } w \mathrm{t})\end{array}$ & $\begin{array}{c}P \\
\left(\mathrm{mg} \mathrm{g}^{-1}\right. \\
\text { dry } w \mathrm{t})\end{array}$ & $\begin{array}{c}\mathrm{K} \\
\left(\mathrm{mg} \mathrm{g}^{-1}\right. \\
\text { dry wt) }\end{array}$ & $\begin{array}{c}\text { Ca } \\
\left(\mathrm{mg} \mathrm{g}^{-1}\right. \\
\text { dry } w t)\end{array}$ & $\begin{array}{c}\mathrm{Mg} \\
\left(\mathrm{mg} \mathrm{g}^{-1}\right. \\
\text { dry wt) }\end{array}$ & $\begin{array}{c}\text { B } \\
\left(\mu g g^{-1}\right. \\
\text { dry } w t)\end{array}$ & $\begin{array}{c}\text { Mn } \\
\left(\mu g g^{-1}\right. \\
\text { dry wt) }\end{array}$ & $\begin{array}{c}\mathrm{Zn} \\
\left(\mu \mathrm{g} \mathrm{g}^{-1}\right. \\
\text { dry } w \mathrm{t})\end{array}$ & $\begin{array}{c}\text { Fe } \\
\left(\mu g g^{-1}\right. \\
\text { dry } w t)\end{array}$ \\
\hline Control & $2.06 \mathrm{a}^{\mathrm{z}}$ & $0.55 \mathrm{a}$ & $2.99 \mathrm{a}$ & $4.25 \mathrm{~b}$ & $0.78 \mathrm{a}$ & $61 \mathrm{a}$ & $60 \mathrm{a}$ & $23 \mathrm{a}$ & $110 \mathrm{a}$ \\
\hline Profical & $2.15 \mathrm{a}$ & $0.59 \mathrm{a}$ & $2.93 \mathrm{a}$ & $4.72 \mathrm{a}$ & $0.75 \mathrm{a}$ & $57 \mathrm{a}$ & $62 \mathrm{a}$ & $24 \mathrm{a}$ & $105 \mathrm{a}$ \\
\hline Chelan Ca & $1.97 \mathrm{a}$ & $0.55 \mathrm{a}$ & $2.96 \mathrm{a}$ & $4.8 \mathrm{a} 2$ & $0.79 \mathrm{a}$ & $61 \mathrm{a}$ & $57 \mathrm{a}$ & $25 \mathrm{a}$ & $108 \mathrm{a}$ \\
\hline F-away Ca & $2.01 \mathrm{a}$ & $0.59 \mathrm{a}$ & $2.79 \mathrm{a}$ & $4.92 \mathrm{a}$ & $0.80 \mathrm{a}$ & $61 \mathrm{a}$ & $64 \mathrm{a}$ & $25 \mathrm{a}$ & $114 \mathrm{a}$ \\
\hline F-away Ca + Profical & $2.17 \mathrm{a}$ & $0.60 \mathrm{a}$ & $2.87 \mathrm{a}$ & $4.88 \mathrm{a}$ & $0.77 \mathrm{a}$ & $55 \mathrm{a}$ & 59 a & $28 \mathrm{a}$ & $111 \mathrm{a}$ \\
\hline F-away $\mathrm{Ca}+$ chelan $\mathrm{Ca}$ & $2.16 \mathrm{a}$ & $0.64 \mathrm{a}$ & $2.86 \mathrm{a}$ & $5.01 \mathrm{a}$ & $0.79 \mathrm{a}$ & 59 a & $58 \mathrm{a}$ & $24 \mathrm{a}$ & $103 a$ \\
\hline
\end{tabular}

${ }^{\mathrm{z}}$ Means within columns and years followed by common letters are not significantly different (Tukey's test, $\left.p \leq 0.05\right)$.

In the kiwifruit cultivar 'Tsechelidis', it was found that foliar sprays with fertilizers containing $\mathrm{Ca}$ increased the Ca concentration of leaves compared to the control [33]. The increase in the Ca concentration of fruits compared to the control was found after the foliar application of Calfruit plus Qualyfruit, Chelan CaP, Power Ca and Acid CaLMg.

Schonherr (2001) [38] studied cuticular penetration using Ca salts. Humidity over cuticles and hygroscopicity of salts significantly affected the rates of penetration. A prerequisite for penetration of ions is the dissolution of the salt, which was determined by the point of deliquescence (POD) of the salt and humidity over the salt residue. Schonherr (2001) [38] concluded that most suitable salts for foliar nutrition should have a low POD such as $\mathrm{CaCl}_{2}$ $(33 \%)$ and $\mathrm{Ca}\left(\mathrm{NO}_{3}\right)_{2}(56 \%)$, whereas salts with a POD above $90 \%$ (for example, Ca-acetate, Ca-lactate and Ca-propionate) are not suitable for foliar nutrition, since penetration causes a humidity rate close to $100 \%$.

Foliar absorption is affected by the presence of $\mathrm{N}$ and amino acids in fertilizers since it is reported that urea promotes the simultaneous influx of other nutrients at both the cuticular and cellular levels [39]. Phloem transport of N occurs mainly in the form of amino acids. Furuya and Umemiya (2002) [40] studied the absorption of $\mathrm{N}$ into peach leaves through 18 kinds of foliar-applied $\mathrm{N}$ chemical forms for the absorption of $\mathrm{N}$ into peach leaves. They reported that urea and inorganic $\mathrm{N}$ sources, especially nitrate- $\mathrm{N}$, were superior as compared to amino acids with respect to $\mathrm{N}$ absorption into the peach leaves. It seems that the composition and the form of $\mathrm{Ca}$ (organic, inorganic, etc.) of these forms of $\mathrm{N}$ exert a significant role in $\mathrm{Ca}$ absorption and transportation.

\section{Conclusions}

In conclusion, the application of the studied commercial Ca fertilizers was beneficial for kiwifruit, since it improved fruit firmness and increased the Ca concentration of leaves and fruits, as well as fruit dry matter at "F-away Ca + Profical" and "F-away Ca + Chelan" $\mathrm{Ca}$ treatments. Treatment differences with regard to fruit firmness, soluble solids concentration and acids at harvest were maintained during cold storage for 2 and 4 months. 
Total soluble solids, total titratable acidity and the mean fruit weight were not affected by the foliar sprays of Ca-containing commercial fertilizers. Finally, these products could be applied as foliar sprays during the growing season starting from fruit set up to prior to harvest as they improve the fruit firmness and storability of kiwifruit.

Author Contributions: Conceptualization, T.S., A.V., T.S.; methodology, I.M., D.K.; software, T.S., O.D.; investigation, T.S., T.C., A.V. and A.M.; resources, T.S.; writing-original draft preparation, T.S., T.C.; writing-review and editing, T.S., O.D.; supervision, T.S.; funding acquisition, T.S. All authors have read and agreed to the published version of the manuscript.

Funding: This research received no external funding.

Conflicts of Interest: The authors declare no conflict of interest.

\section{References}

1. Bonomelli, C.; Ruiz, R. Effects of foliar and soil calcium application on yield and quality of table grape cv. 'Thompson seedless'. J. Plant Nutr. 2010, 33, 299-314. [CrossRef]

2. Yamaguchi, T.; Hara, T.; Sonoda, Y. Distribution of calcium and boron in the pectin fraction of tomato leaf cell wall. Plant Cell Physiol. 1986, 27, 729-732.

3. Conway, W.S.; Sams, C.E.; Brown, G.A.; Beavers, W.S.; Tobias, R.B.; Kennedy, L.S. Pilot test for the commercial use of postharvest pressure infiltration of calcium into apples to maintain fruit quality in storage. HortTechnology 1994, 4, 239-243. [CrossRef]

4. Ciccarese, A.; Stellacci, A.M.; Gentilesco, G.; Rubino, P. Effectiveness of pre- and postveraison calcium applications to control decay and maintain table grape fruit quality during storage. Postharvest Biol. Technol. 2013, 75, 135-141. [CrossRef]

5. Fattahi, J.; Fifall, R.; Babri, M. Postharvest quality of Kiwifruit (Actinidia deliciosa cv. Hayward) affected by pre-storage application of salicylic acid. South West. J. Hortic. Biol. Environ. 2010, 1, 175-186.

6. Hocking, B.; Tyerman, S.D.; Burton, R.A.; Gilliham, M. Fruit calcium: Transport and physiology. Front. Plant Sci. 2016, 29 , 569. [CrossRef]

7. Mengel, K.; Kirkby, E.A. Principles of Plant Nutrition, 5th ed.; Kluwer Academic Publishers: Dordrecht, The Netherlands, 2001.

8. Xiloyannis, C.; Dichio, B.; Montanaro, G.; Lang, A.; Celano, G.; Mazzeo, M. Fruit morphological and physiological traits influence calcium transport and accumulation in kiwifruit. Acta Hortic. 2008, 767, 369-377. [CrossRef]

9. Epstein, E.; Bloom, A. Mineral Nutrition of Plants: Principles and Perspectives, 2nd ed.; Sinauer Associates: Sunderland, MA, USA, 2008.

10. Raven, J.A. $\mathrm{H}^{+}$and $\mathrm{Ca}^{2+}$ in phloem and symplast: Relation of relative immobility of the ions to the cytoplasmic nature of the transport paths. New Phytol. 1977, 79, 465-480. [CrossRef]

11. Swietlik, D.; Faust, M. Foliar nutrition of fruit crops. Hortic. Rev. 1984, 6, 287-355.

12. Bukovac, M.J.; Wittwer, S.H. Absorption and mobility of foliar applied nutrients. Plant Physiol. 1957, 32, 428-435. [CrossRef]

13. Lang, A. Xylem, phloem and transpiration flows in developing apple fruits. J. Exp. Bot. 1990, 41, 645-651. [CrossRef]

14. Saure, M.C. Calcium translocation to fleshy fruit: Its mechanism and endogenous control. Sci. Hortic. 2005, 105, 65-89. [CrossRef]

15. Montanaro, G.; Dichio, B.; Lang, A.; Mininni, A.N.; Nuzzo, V.; Clearwater, M.J.; Xiloyannis, C. Internal versus external control of calcium nutrition in kiwifruit. J. Plant Nutr. Soil Sci. 2014, 177, 819-830. [CrossRef]

16. Morandi, B.; Losciale, P.; Manfrini, L.; Pierpaoli, E.; Zibordi, M.; Grappadelli, L.C. Short-period changes in weather conditions affect xylem, but not phloem flows to young kiwifruit (Actinidia deliciosa) berries. Sci. Hortic. 2012, 142, 74-83. [CrossRef]

17. McLaughlin, S.B.; Wimmer, R. Ca physiology and terrestrial ecosystem processes. New Phytol. 1999, 142, 373-417. [CrossRef]

18. Pate, J.S.; Gunning, B.E.S. Transfer cells. Ann. Rev. Plant Physiol. 1972, 23, 173-196. [CrossRef]

19. Park, S.; Cheng, N.H.; Pittman, J.K.; Yoo, K.S.; Park, J.; Smith, R.H.; Hirschi, K.D. Increased calcium levels and prolonged shelf life in tomatoes expressing Arabidopsis $\mathrm{H}^{+} / \mathrm{Ca}^{2+}$ transporters. Plant Physiol. 2005, 139, 1194-1206. [CrossRef]

20. Montanaro, G.; Dichio, B.; Lang, A.; Mininni, A.N.; Xiloyannis, C. Fruit calcium accumulation coupled and uncoupled from its transpirationin kiwifruit. J. Plant Physiol. 2015, 181, 67-74. [CrossRef]

21. Franceschi, V.R.; Nakata, P.A. Calcium oxalate in plants: Formation and function. Ann. Rev. Plant Biol. 2005, 56, 41-71. [CrossRef]

22. Gilliham, M.; Dayod, M.; Hocking, B.J.; Xu, B.; Conn, S.J.; Kaiser, B.N. Calcium delivery and storage in plant leaves: Exploring the link with water flow. J. Exp. Bot. 2011, 62, 2233-2250. [CrossRef]

23. Dilmaghani, M.R.; Malakouti, M.J.; Neilsen, G.H.; Fallahi, E. Interactive effects of potassium and calcium on K/Ca ratio and its consequences on apple fruit quality in calcareous soils. J. Plant Nutr. 2005, 27, 1149-1162. [CrossRef]

24. Sale, P.; Lyford, P. Cultural, management and harvesting practices for kiwifruit in New Zealand. In Kiwifruit Science and Management; Warrington, I.J., Weston, G.C., Eds.; New Zealand Society for Horticultural Science: Palmerston North, New Zealand, 1990; p. 576.

25. Page, A.L.; Miller, R.H.; Keeney, D.R. Chemical and microbiological properties. In Methods of Soil Analysis; Page, A.L., Miller, R.H., Keeney, D.R., Eds.; ASASSSA: Madison, WI, USA, 1982; pp. 431-436.

26. Wolf, B. Improvement in the azomethine-H method for the determination of boron. Commun. Soil Sci. Plant Anal. 1974, 5, 39-44. [CrossRef]

27. Jackson, D.I. Soil Chemical Analysis-Advanced Course, 2nd ed.; University of Wisconsin: Madison, WI, USA, 1969. 
28. Ough, C.S.; Amerine, M.A. Methods Analysis of Musts and Wines; John Wiley and Sons: New York, NY, USA, 1988.

29. Schotsmans, W.C.; Mawson, A.J.; MacKay, B. Comparison of destructive and non-destructive (NIR) dry matter determination for HORT16A (ZESPRI ${ }^{\mathrm{TM}}$ GOLD) kiwifruit. Acta Hortic. 2007, 753, 283-288. [CrossRef]

30. Gerasopoulos, D.; Chouliaras, V.; Lionakis, S. Effects of preharvest calcium chloride sprays on maturity and storability of Hayward kiwifruit. Postharvest Biol. Technol. 1996, 7, 65-72. [CrossRef]

31. Hashmatt, M.; Morton, A.R.; Heyes, J.A.; Armour, D.; Lowe, T.; Black, M.; Kerckhoffs, L.H.J. Effect of pre-harvest foliar calcium application on fruit quality in gold 3 kiwifruit. Acta Hortic. 2019, 1253, 327-334. [CrossRef]

32. Honarkarian, F.; Torkashvand, A. Effect of different calcium chloride application methods and macro elements fertilizers (nitrogen, phosphorus and potassium) on fruit quality and postharvest life of Hayward Kiwi Fruit. Plant Prod. Technol. 2018, 10, 189-199.

33. Koutinas, N.; Sotiropoulos, T.; Petridis, A.; Almaliotis, D.; Deligeorgis, E.; Therios, I.; Voulgarakis, N. Effects of preharvest calcium foliar sprays on several fruit quality attributes and nutritional status of the kiwifruit cultivar 'Tsechelidis'. HortScience 2010, 45, 984-987. [CrossRef]

34. Pekmezci, M.; Erkan, M.; Gubbuk, M.; Karasahin, I.; Uzun, I. Modified atmosphere and ethylene absorbent enables prolonged storage of Hayward kiwifruit. In Proceedings of the XXVI International Horticultural Congress: Citrus and Other Subtropical and Tropical Fruit Crops, Toronto, ON, Canada, 29 February 2004; Volume 632, pp. 337-341.

35. Hopkirk, G.; Harker, F.R.; Harman, J.E. Calcium and the firmness of kiwifruit. N. Z. J. Crop Hortic. Sci. 1990, 18, 215-219. [CrossRef]

36. Shiri, M.; Ghasemnezhad, M.; Moghadam, J.; Ebrahimi, R. Effect of $\mathrm{CaCl}_{2}$ sprays at different fruit development stages on postharvest keeping quality of "Hayward" kiwifruit. J. Food Process. Preserv. 2016, 40, 624-635. [CrossRef]

37. Cooper, T.; Gargiullo, A.; Streif, J.; Retamales, J. Effects of calcium content and calcium applications on softening of Hayward kiwifruit. Acta Hortic. 2007, 753, 297-304. [CrossRef]

38. Schonherr, J. Cuticular penetration of calcium salts: Effects of humidity, anions, and adjuvants. J. Plant Nutr. Soil Sci. 2001, 164, 225-231. [CrossRef]

39. Weinbaum, S.A. Foliar nutrition of fruit trees. In Plant Growth and Leaf Applied Chemicals; Neumann, P.N., Ed.; CRC Press: Boca Raton, FL, USA, 1988; pp. 81-100.

40. Furuya, S.; Umemiya, Y. The influence of chemical forms on foliar-applied nitrogen absorption for peach trees. Acta Hortic. 2002, 594, 97-103. [CrossRef] 